Tropical Journal of Pharmaceutical Research January 2018; 17 (1): 65-70

ISSN: $1596-5996$ (print); 1596-9827 (electronic)

(C) Pharmacotherapy Group, Faculty of Pharmacy, University of Benin, Benin City, 300001 Nigeria.

Available online at http://www.tjpr.org

Original Research Article

http://dx.doi.org/10.4314/tjpr.v17i1.10

\title{
In vitro anti-tumor activity in SGC-7901 human gastric cancer cells treated with dandelion extract
}

\author{
Hui Han ${ }^{1}$, Geng Zhen Chen ${ }^{1 *}$, Sheng Kang Zhou ${ }^{2}$, Rui Ru1 Xu', Cheng Liang \\ $\mathrm{Wu}^{1}$ \\ ${ }^{1}$ Department of General Surgery, The Second Affiliated Hospital of Shantou Medical College, Shantou, ${ }^{2}$ Department of \\ Gastrointestinal Surgery, Tai Zhou Hospital, Tai Zhou City, People's Republic of China
}

*For correspondence: Email: hjbmopvb@sina.com

Sent for review: 16 August 2017

Revised accepted: 17 October 2017

\begin{abstract}
Purpose: To investigate the mechanisms of cytotoxicity of a dandelion extract against human gastric cancer cell line SGC-7901 cells.

Methods: The 3-(4,5-dimethyl-2-thiazolyl)-2,5-diphenyl-2-H-tetrazolium bromide (MTT) assay, flow cytometry, and transwell assays were used to investigate the effects of a dandelion extract on cell proliferation, levels of apoptosis, and cell migration, respectively. Reverse transcription-quantitative polymerase chain reaction (RT-qPCR) assessed the effects of a dandelion extract on the expression levels of genes regulating proliferation and apoptosis.

Results: Dandelion extract exerted strong cytotoxic effects on the cancer cells. After exposure, apoptotic cells increased and cell migration was reduced. RT-qPCR assay revealed that dandelion extract significantly increased anti-proliferative and pro-apoptotic gene expression, including phosphate and tensin homology deleted on chromosome ten (Pten) and Bcl-2 Associated X protein (Bax) mRNA in the gastric cancer cells. The results also indicate that there was decreased pro-proliferative and antiapoptotic gene expression (i.e., extracellular signal-regulated kinase (Erk), Survivin, and B-cell lymphoma 2 (Bc/2) $m R N A)$.

Conclusion: The results suggest that dandelion extract is a potent gastric cancer cell proliferation, survival, and migration inhibitor with potential pharmaceutical applications for the prevention of gastric cancer.
\end{abstract}

Keywords: dandelion extract, gastric cancer, cytotoxic effect, migration inhibition

\begin{abstract}
This is an Open Access article that uses a funding model which does not charge readers or their institutions for access and distributed under the terms of the Creative Commons Attribution License (http://creativecommons.org/licenses/by/4.0) and the Budapest Open Access Initiative (http://www.budapestopenaccessinitiative.org/read), which permit unrestricted use, distribution, and reproduction in any medium, provided the original work is properly credited.

Tropical Journal of Pharmaceutical Research is indexed by Science Citation Index (SciSearch), Scopus, International Pharmaceutical Abstract, Chemical Abstracts, Embase, Index Copernicus, EBSCO, African Index Medicus, JournalSeek, Journal Citation Reports/Science Edition, Directory of Open Access Journals (DOAJ), African Journal Online, Bioline International, Open-J-Gate and Pharmacy Abstracts
\end{abstract}

\section{INTRODUCTION}

Gastric cancer incidence is rapidly increasing worldwide [1]. More than one million cases are detected annually [2]. Standard therapies include surgery, and chemo- and radiotherapy. Many patients' gastric cancers are refractory to chemoand radiotherapy or patients have metastatic disease at presentation, or both. These poor responses severely reduce the benefits of local surgical procedures. These challenges significantly affect the survival outcomes and 
quality-of-life for gastric cancer patients. Because the incomplete effectiveness of standard therapies, alternative strategies to improve gastric cancer patient outcomes have been sought. More recently, selective induction of cell death, or apoptosis, within cancers has emerged as a possible therapeutic alternative [3]. One method to selectively induce apoptosis of cancer cells involves the use of natural plant extracts [4].

Dandelion (Taraxacum spp.) is a perennial herb grown throughout the world, especially in the Northern Hemisphere's relatively temperate environments. Dandelion is widely considered a weed. However, it contains many useful phytochemicals such as flavonoids, phenolic acids, alkaloids, and terpenes [5]. Over 30 phenolic compounds have been isolated from dandelion [6]. Oriental medicine has traditionally recognized the value of dandelion extract for the treatment of bladder, spleen, and liver ailments, and for diseases such as gout and diarrhea [710]. In this study, our aim was to determine whether a dandelion extract possessed antitumor activity that can be exploited for treatment of gastric cancer.

\section{METHODS}

\section{Materials}

The human gastric cancer SGC-7901 cells were purchased from Shanghai ZeYe Company (Shanghai City, China). Herbal samples of dandelion were collected (ShanTou City, GuangZhou Province, China) in June 2016 (voucher specimen no. SOLE 201606041, Department of Pharmacy, TaiZhou Hospital, China). Prof. ShengKang Zhou (TaiZhou Hospital, China) identified the plant using taxonomic characteristics.

The dandelion extract was prepared at a Shantou University laboratory as follows: dandelion plants were placed in a round bottom flask with water $(1: 7, \mathrm{w} / \mathrm{v})$ for reflux extraction at $100{ }^{\circ} \mathrm{C}$; extraction was performed twice for $3 \mathrm{~h}$ each time. Next, a rotary evaporator was used to remove the water, and the remaining solution was concentrated into a $150-\mathrm{mL}$ volume via further evaporation of the extract.

\section{Proliferation assay}

A 3-(4,5-dimethyl-2-thiazolyl)-2,5-diphenyl-2-Htetrazolium bromide (MTT) assay [11], with some modifications, was used to measure activity of the extract on SGC-7901 cell proliferation. The cells were added to 96 -well microculture plates at a $5 \times 10^{3}$ cells/well density, were grown overnight, and the supernatant was removed. The cells were then incubated in growth medium including $10 \%$ fetal bovine serum. The extract was added to the wells at varying concentrations. The cells were then incubated for $48 \mathrm{~h}$. After incubation, the medium was replaced with $20 \mu \mathrm{L}$ MTT reagent (from $5 \mathrm{mg} / \mathrm{mL}$ stock solution) and the cells were incubated for $4 \mathrm{~h}\left(37^{\circ} \mathrm{C}, 5 \% \mathrm{CO}_{2}\right)$. The MTT reagent was then removed and DMSO $(150 \mu \mathrm{L})$ was added to each well. The plates were shaken for $30 \mathrm{~min}$ using a table oscillator. The results were analyzed using a plate reader $(570 \mathrm{~nm}$ wavelength; Molecular Devices Inc., San Francisco, CA, USA). Mean values were calculated from the results obtained from three assays of each sample.

\section{Apoptosis assay}

An Annexin V Apoptosis Detection Kit (SigmaAldrich, MO, USA) was used to assess apoptosis; $10^{6}$ cells $/ \mathrm{mL}$ of SGC-7901 cells were plated and incubated overnight, before a $48 \mathrm{~h}$ treatment with the dandelion extract. After exposure to the extract, the cells were harvested, then rinsed once with PBS and resuspended in binding buffer (Annexin V). Finally, Annexin V $(5 \mu \mathrm{L})$ and propidium iodide $(10 \mu \mathrm{L})$ were added to the cell suspension. The sample was then incubated in the dark for $10 \mathrm{~min}$ at room temperature. Flow cytometry analysis was then performed. Cell populations with differential uptakes of Annexin $\mathrm{V}$ and propidium iodide were detected using a BD LSRFortessa ${ }^{\mathrm{TM}}$ Cell Analyzer (Becton Dickinson, NJ, USA).

\section{Transwell migration assay}

A Millicell-24 Cell Culture Insert Plate (BD BioCoat Control Inserts, BD Biosciences) was used to measure SGC-7901 cell migration during transwell assay. The cells were grown to $80 \%$ confluence, followed by serum starvation overnight before the experiment was performed. Briefly, the cells were harvested, resuspended in starvation medium, and added at a $5 \times 10^{4}$ cells per well density $(0.3 \mathrm{~mL}$ volume $)$ in the upper well. This upper well was immersed in a lower well containing complete medium to which was added varying concentrations of allicin or $10 \%$ fetal calf serum. After a 48 -h incubation $\left(37^{\circ} \mathrm{C}, 5\right.$ $\left.\% \quad \mathrm{CO}_{2}\right)$, the experiment was stopped. Membranes from the transwell chambers were fixed with methanol for 15 min, followed by incubation with a Giemsa staining solution for $20 \mathrm{~min}$. The membranes were then dried (room temperature), and cell migration was determined by counting the cell numbers in 10 unbiased fields-of-view under a microscope [12]. 


\section{Quantification of mRNA}

RNeasyMini Kit columns (Qiagen) were used to isolate the total RNA from the SGC-7901 cells, following the manufacturer's instructions. One milligram previously isolated total RNA was used for the cDNA synthesis for RT-qPCR; the QuantiTectH Reverse Transcription (Qiagen) protocol was used per the manufacturer's instructions (using hexamer priming). A LightCycler 480 system (Roche Diagnostics) and LightCycler SYBR Green I Master (Roche Diagnostics) were used for the RT-qPCR. The reaction mixture $(10 \mu \mathrm{L})$ was subjected to 50 amplification cycles $\left(10 \mathrm{~s}\right.$ at $95{ }^{\circ} \mathrm{C}, 60 \mathrm{~s}$ at 60 $\left.{ }^{\circ} \mathrm{C}\right)$. The primers were used at a final concentration of $10 \mathrm{mM}$ per reaction mixture. Primer 3 software was used for the primer design (Table 1).

Table 1: Primer sequences

\begin{tabular}{ll}
\hline Gene & Sequence \\
\hline Pten & 5' TTTGAAGACCATAACCCACCAC 3' \\
& 5' ATTACACCAGTTCGTCCCTTTC 3' \\
Erk & 5' TCACACAGGGTTCCTGACAGA 3' \\
& 5' ATGCAGCCTACAGACCAAATATC 3' \\
Bcl2 & 5'-CGACTTCGCCGAGATGTCCAGCCAG- \\
& 3' \\
& 5'-ACTTGTGGCCCAGAGGCACCCAg-3' \\
Bax & 5'-GGCCCACCAGCTCTGAGCAGA-3' \\
Survivi & 5'-GCCACGTGGGCGTCCCAAAGT-3' \\
$n$ & 5'-CGGCATGGGTGCCCCGACGTTG-3' \\
Actin & 5'-TTGAGGCCTCTGGCCGGAGC-3' \\
& ATCTGGCACCACACCTTCTACAATGAGC \\
& TGCG-3' \\
& 5'- \\
& CGTCATACTCCTGCTTGCTGATCCACAT \\
& CTGC-3' \\
\hline
\end{tabular}

\section{Statistical analysis}

The results were calculated as mean \pm standard deviation values. One-way analysis of variance (SPSS software, version 21, SPSS Inc., Chicago, IL, USA) was used to test for statistically significant differences between the untreated, control groups and the treated, experimental groups. A post-hoc multiple comparison test was used to calculate least significant differences. $P 0.05$ was used to determine statistical significance.

\section{RESULTS}

To determine the efficacy of a natural plant extract in gastric cancer inhibition, we exposed SGC-7901 cells to a dandelion extract. After a 48-h exposure to increasing concentrations ( 0 , $0.2, \quad 0.25$ or $0.3 \mathrm{mg} / \mathrm{mL}$ ), phase-contrast microscopy revealed differences in cellular morphology (data not shown). The effects of the extract on cell growth were investigated using MTT assay. The extract had dose and timedependent growth inhibition effects (Figure 1). Maximum inhibition of proliferation was observed at $48 \mathrm{~h} ; 500 \mu \mathrm{g} / \mathrm{ml} \mathrm{GPE}$ inhibited proliferation in $72.14 \pm 6.03 \%$ of the cells.

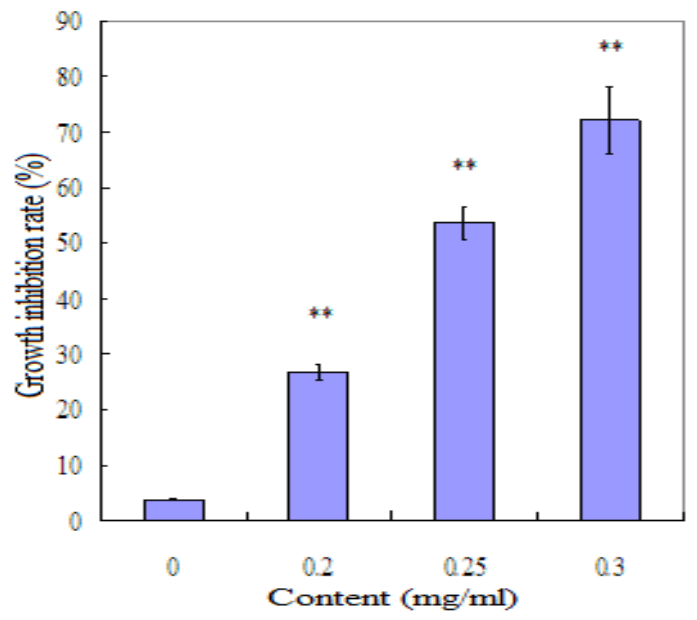

Figure 1: Dandelion extract affects SGC-7901 cell proliferation

Cells were exposed to concentrations of $0,0.2$, 0.25 , or $0.3 \mathrm{mg} / \mathrm{mL}$ extract for $48 \mathrm{~h}$ to examine the effect on apoptosis. The Annexin V assay revealed that there were statistically significant, dose-dependent increases in the percentages of apoptotic cells after treatment with the dandelion extract (Figure 2).

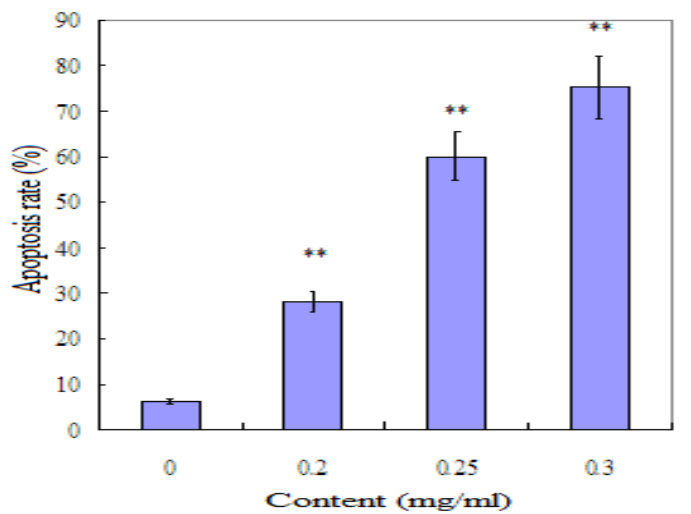

Figure 2: Dandelion extract affects apoptosis of SGC7901 cells

Next, we used Transwell migration assay to examine the effects of the dandelion extract on inhibition of migration. Cells were exposed to the extract at concentrations of $0,0.2,0.25$, or $0.3 \mathrm{mg} / \mathrm{mL}$ for $48 \mathrm{~h}$. The results indicated that the percentage of migration inhibition increased with increasing concentrations of the extract (Fig. 3). There were statistically significant differences $(p<0.01)$ between the dandelion extract-treated compared with the control, untreated, cells. The 
transwell assay revealed that dandelion extract could suppress SGC-7901 cell migration in vitro.

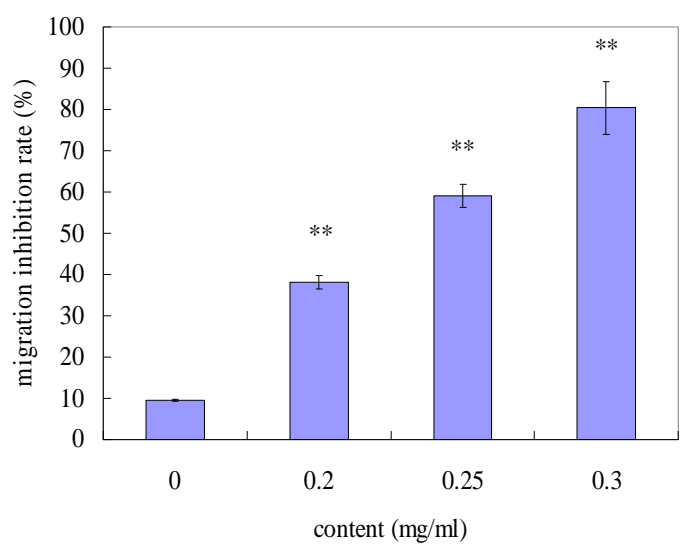

Figure 3: Dandelion extract affects migration of SGC-7901 cells

To examine mechanisms of cell growth inhibition, the expression of genes involved in the regulation of proliferation and apoptosis were assessed using RT-qPCR. After a 48-h treatment with the dandelion extract, the levels of expression of pro-apoptotic genes were significantly increased (phosphate and tensin homology deleted on chromosome ten (Pten) $(p$ $<0.05)$ and Bcl-2 Associated X protein (Bax) $(p<$ 0.01)) (Table 2). In contrast, levels of expression of anti-apoptotic and pro-proliferative genes, such as extracellular signal-regulated kinase (Erk), B-cell lymphoma 2 (Bc/2), and Survivin, were significantly decreased $(p<0.01)$.

\section{DISCUSSION}

The incidence of gastric cancer continues to increase worldwide at a rate of approximately one million new cases annually. Most patients are diagnosed at late stages of disease when standard treatment strategies, such as surgery, and radio- and chemotherapy, are generally less effective [13]. Natural compounds extracted from Chinese herbs have emerged as alternative therapeutic options. These natural compounds are used to effectively treat infections, inflammation, cardiac diseases, hypertension, and cancers with many fewer side effects compared with conventional therapies [14,15].
We therefore sought to determine whether a natural extract from dandelion has any antigastric cancer activity. The results revealed that the dandelion extract had statistically significant inhibitory effects on the SGC-7901 cells. Quantitative assays revealed that the extract mediated this inhibitory effect by decreasing cellular proliferation and promoting apoptosis.

Invasion and metastasis are the main causes for poor outcomes in gastric cancer patients and are considered essential features of cancer. Therefore, in addition to inducing apoptosis of the primary tumor, inhibiting metastasis is critical for long-term cancer prevention. In this study, we observed a dose-dependent inhibition of SGC7901 cells after 48-h exposure to dandelion extract.

To identify the mechanism via which the extract promoted apoptosis, we examined the expression of known regulators of apoptosis. The intrinsic (i.e., mitochondrial mediated) and extrinsic (i.e., death receptor mediated) pathways are the two major pathways that mediate apoptosis. BCL2 and SURVIVIN inhibit apoptosis, but they mediate it via different pathways. The anti-apoptotic protein BCL2 primarily inhibits the intrinsic pathway [16]. SURVIVIN inhibits the activation of downstream caspases that coordinate apoptosis following intrinsic and extrinsic cues [17]. The results revealed dose-dependent decreases in Bcl2 and Survivin expression levels.

Relative concentrations of BAX (pro-apoptotic) and BCL2 (anti-apoptotic) proteins determine cell survival and apoptosis [16]. BAX promotes apoptosis via direct inhibition of BCL2. There were dose-dependent increases in Bax levels after treatment with dandelion extract.

ERK acts downstream of the MAP kinase pathway; results suggest that it regulates cell growth, survival, and autophagy [18-20]. The lipid phosphatase PTEN is required for Sprouty 2 (SPRY2)-mediated inhibition of protein kinase $B$ (PKB)/AKT activation and subsequent cell proliferation [21].

Table 2: Effect of dandelion extract treatment on gene expression in SGC-7901 cells

\begin{tabular}{llllll}
\hline Content(mg/ml) & PTEN & ERK & BCL-2 & BAX & SURVIVIN \\
\hline 0 & $1.05 \pm 0.03$ & $1.06 \pm 0.04$ & $1.03 \pm 0.01$ & $1.08 \pm 0.02$ & $1.01 \pm 0.06$ \\
0.20 & $1.27 \pm 0.08^{*}$ & $0.73 \pm 0.02^{\star *}$ & $0.82 \pm 0.02^{* *}$ & $1.23 \pm 0.09^{*}$ & $0.91 \pm 0.07$ \\
0.25 & $1.42 \pm 0.11^{* *}$ & $0.49 \pm 0.01^{\star *}$ & $0.61 \pm 0.03^{* *}$ & $1.42 \pm 0.11^{* *}$ & $0.58 \pm 0.03^{\star *}$ \\
0.30 & $1.58 \pm 0.14^{* *}$ & $0.28 \pm 0.01^{\star *}$ & $0.43 \pm 0.03^{\star *}$ & $1.64 \pm 0.09^{* *}$ & $0.33 \pm 0.01^{\star *}$ \\
\hline${ }^{\star} P<0.05,{ }^{* *} p<0.01$, compared with untreated control $(0 \mathrm{mg} / \mathrm{ml})$. Fold=changes are normalized to housekeeping \\
gene expression (Actin)
\end{tabular}


Furthermore, PTEN inhibits the (PI3K)/AKT pathway via phosphatidylinositol $3,4,5$ phosphate $\left(\mathrm{PIP}_{3}\right)$ dephosphorylation. Pten mRNA expression increased and Erk expression decreased after treatment of SGC-7901 cells with the extract. Taken together, the study revealed a gene expression pattern associated with decreased cellular survival and proliferation in response to treatment of gastric cancer cells with a dandelion extract.

\section{CONCLUSION}

Dandelion extract inhibits SGC-7901 cell proliferation and induces apoptosis, possibly via regulation of Bax, Bcl2, Survivin, Pten, and Erk gene expression. These results suggest a potential use for dandelion extract as an alternative therapy for gastric cancer patients.

\section{DECLARATIONS}

\section{Acknowledgement}

The authors thank our laboratory colleagues for their assistance.

\section{Conflict of interest}

No conflict of interest is associated with this work.

\section{Contribution of authors}

We declare that this work was done by the authors named in this article and all liabilities pertaining to claims relating to the content of this article will be borne by the authors.

\section{REFERENCES}

1. Parkin DM, Bray F, Ferlay J, Pisani P. Global cancer statistics, 2002. CA Cancer J Clin 2005; 55: 74-108

2. Fan $Y Y$, Yang $B Y, W u$ CY. Phenotypically and functionally distinct subsets of natural killer cells in human PBMCs. Cell Biol Int 2008; 32: 188-197

3. Fulda S, Debatin KM. Targeting apoptosis pathways in cancer therapy. Curr Cancer Drug Tar 2004; 7: 569-576

4. Ji YB, Qu ZY, Zou X. Juglone-induced apoptosis in human gastric cancer SGC-7901 cells via the mitochondrial pathway. Exp Toxicol Pathol 2011; 63: 69-78

5. Kisiel W, Barszcz B. Further sesquiterpenoids and phenolics from Taraxacum officinale. Fitoterapia 2000; 71 (3) : 269-273

6. Gonzalez-Castejon M, Visioli F, Rodriguez-Casado A. Diverse biological activities of dandelion. Nutr Rev 2012; 70 (9): 534-547
7. Martinez $M$, Poirrier $P$, Chamy $R$, Prufer $D$, SchulzeGronover $C$, Jorquera L, Ruiz G. Taraxacum officinale and related species - an ethnopharmacological review and its potential as a commercial medicinal plant. $J$ Ethnopharmacol 2015; 169: 244-262

8. Hu C, Kitts $D D$. Dandelion (Taraxacum officinale) flower extract suppresses both reactive oxygen species and nitric oxide and prevents lipid oxidation in vitro. Phytomedicine 2005; 12: 588-597

9. Gargouri M, Ghorbel-Koubba F, Bonenfant-Magne M, Ch Magne, Dauvergne X, Ksouri R, Krichen Y, Abdelly C, El Feki A. Spirulina or dandelion-enriched diet of mothers alleviates lead-induced damages in brain and cerebellum of new born rats. Food Chem Toxicol 2012; 50: 502303-502310

10. Hassan HA, El-Kholy WM, Galal NA. Comparative protective effect of moringa and dandelion extracts against hepatic disorders and oxidative stress associated with prolonged use of brufen drug in rats. Egypt J Hosp Med 2015; 60: 336-346

11. Wu GE, Hozumi N, Murialdo H. Secretion of a lambda 2 immunoglobulin chain is prevented by a single amino acid substitution in its variable region. Cell 1983; 33(1):77-83.

12. Karki R, Jeon ER, Kim DW. Magnoliae Cortex inhibits intimal thickening of carotid artery through modulation of proliferation and migration of vascular smooth muscle cells. Food Chem Toxicol 2012; 50(3-4): 634-640.

13. Pasechnikov V, Chukov S, Fedorov E, Kikuste I, Leja M. Gastric cancer: prevention, screening and early diagnosis. World J Gastroenterol 2014; 20: 13842

14. Middleton Jr E, Kandaswami C, Theoharides TC. The effects of plant flavonoids on mammalian cells: implications for inflammation, heart disease, and cancer. Pharmacol Rev 2000; 52: 673-751

15. Kandaswami C, Lee LT, Lee PP, Hwang JJ, Ke FC, Huang YT, Lee MT. The antitumor activities of flavonoids. In vivo 2005; 19: 895-909

16. Kirkin V, Joos S, Zornig M. The role of Bcl-2 family members in tumorigenesis. Biochim Biophys Acta 2004; 1644: 229-249

17. Suzuki A, Ito $T$, Hayashida M, Hayasaki $Y$, Tuutomi $Y$, Akahane K, Nakano T, Miura M, Shiraki K. Survivin initiates procaspase 3/p21 complex formation as a result of interaction with Cdk4 to resist Fas-mediated cell death. Oncogene, 2000; 19: 1346-1353

18. Hung AC, Tsai CH, Hou MF, Chang WL, Wang CH, Lee YC, Ko A, Hu SC, Chang FR, Hsieh PW, Yuan SF. The synthetic beta-nitrostyrene derivative CYT-Rx20 induces breast cancer cell death and autophagy via ROSmediated MEK/ERK pathway. Cancer Lett 2015; 371: 251-261

19. Li T, Xu XH, Tang ZH, Wang YF, Leung $C H$, Ma $D L$, Chen XP, Wang YT, Chen $Y$, Lu JJ. Platycodin $D$ induces apoptosis and triggers ERK- and JNK-mediated autophagy in human hepatocellular carcinoma BEL7402 cells. Acta Pharmacol Sin 2015; 36: 1503-1513 
Han et al

20. Liu X, Wang N, Zhu Y, Yang Y, Chen X, Chen Q, Zhou H, Zheng J. Extracellular calcium influx promotes antibacterial autophagy in $E$. coli infected murine macrophages via CaMKKbeta dependent activation of ERK1/2, AMPK and FoxO1. Biochem Biophys Res Commun 2015; 469: 639-645
21. Edwin F, Singh R, Endersby R, Baker SJ, Patel TB. The tumor suppressor PTEN is necessary for human sprouty 2-mediated inhibition of cell proliferation. $J$ Biol Chem 2006; 281: 4816-4822. 